Teaching \& Learning (2015) 9(1), 1-15

\title{
Creating Links between the School and the Community Beyond its Walls: What Teachers and Principals Do to Develop and Lead School-Community Partnerships
}

\author{
CATHERINE HANDS \\ Brock University
}

\begin{abstract}
For some time now, educational researchers have been talking about the benefits of partnerships between schools, families and communities as a way to boost student achievement and wellbeing (see for example Epstein, 2001; Epstein \& Sanders, 1998; Henderson \& Mapp, 2002; Henderson, Mapp, Johnson, \& Davies, 2007; Sheldon, 2005). A number of schools and their boards are arriving at the same conclusion by creating policies designed to encourage community involvement, and developing school-community relations (Sanders, 1999). Seven stages of the partnership process are discussed through key questions that guide educators in this work. A list of the types of partners identified in the literature is provided, as well as sample activities that school personnel could develop at their sites. This paper is based on research in the area of school-community collaboration, and is intended to provide an overview of the process of developing school-community relationships for those educators who may wish to establish them.
\end{abstract}

\section{Introduction}

The importance of community involvement in education has "taken on the force of common sense” (Anderson, 1998, p. 572, as cited in Schutz, 2006, p. 691) for educators and policy makers. For some time now, educational researchers have been talking about the benefits of partnerships between schools, families and communities as a way to boost student achievement and wellbeing (see for example Epstein, 2001; Epstein \& Sanders, 1998; Henderson \& Mapp, 2002; Henderson, Mapp, Johnson, \& Davies, 2007; Sheldon, 2005). A number of schools and their boards are arriving at the same conclusion (Sanders, 1999), and have created policies for collaboration (Hands, 2005b). Similarly, governments are recognizing the importance of community involvement, particularly in regions identified as economically challenged. For example, Ontario’s Ministry of Education has policies and financial support for urban high schools to develop programs in partnership with their community (Ontario Ministry of Education, 2005). 
It is one thing to know that community involvement in education is a good idea; it is quite another to develop relationships that promote community participation. School-community collaboration in education is not widespread, especially in marginalized areas (Schutz, 2006); community members are often involved in their schools peripherally, if at all. Some scholars stress the importance of close links between schools and communities, in order for education to meet the needs of society (Crowson \& Boyd, 2001). They observe that the cost to students of not creating community involvement opportunities is substantial. Without school-community collaboration, the in-school and out-of-school learning opportunities are limited to the resources available through the schools and school boards, and these are too often insufficient to meet the needs of school programs and a diverse student population (Hands, 2005b; Henderson et al., 2007; Merz \& Furman, 1997). Opportunities to build social capital through access to individuals in the community and their resources (Lin, 1999), such as social networks within the community and potential work experience, are limited without school-community collaboration (cf. Coleman, 1988; Hands, 2005b; Lin, 1999). Opportunities for social capital development are especially crucial for students from low-income or ethnic minority backgrounds, who may not have otherwise have the access through their personal or familial relationships that their more privileged peers have (Hands, 2014). Educators, community mentors and students alike consider consistent messages of support for students' academic work from the school personnel and community members, are among the most important facilitators of educational success (Epstein, 2001; Shapiro, Ginsberg, \& Brown, 2002). As one educator observed:

I think education is a community responsibility. It's not just my responsibility or [other teachers'] responsibility to educate. It is bigger than [that], and if it's left just to us, the educators, then it's not going to happen to its fullest potential. (Hands, 2005a, pp. 113-114)

This educator is not alone. There are other educators who want to collaborate. In addition to policies encouraging community involvement, some school boards have community liaison personnel at the central office to help educators and families connect with services and organizations in the community (Hands, 2005b). How can these resources be used, and how do we move from policy to practice? Specifically, how do educators and community members go about creating collaborative activities that support students? 


\section{The Process for Creating School-Community Collaborative Activities: An Interaction Lifecycle}

Research in the area of school-community relations sheds some light on how educators and their community partners successfully work together (see for example Hands, 2005b; Gregoric, 2013; Sanders, 1999; Sanders, 2003; Wohlstetter, Malloy, Smith, \& Hentschke, 2003). Developing relationships takes place over a series of stages (Hands, 2005b) (see Figure 1).

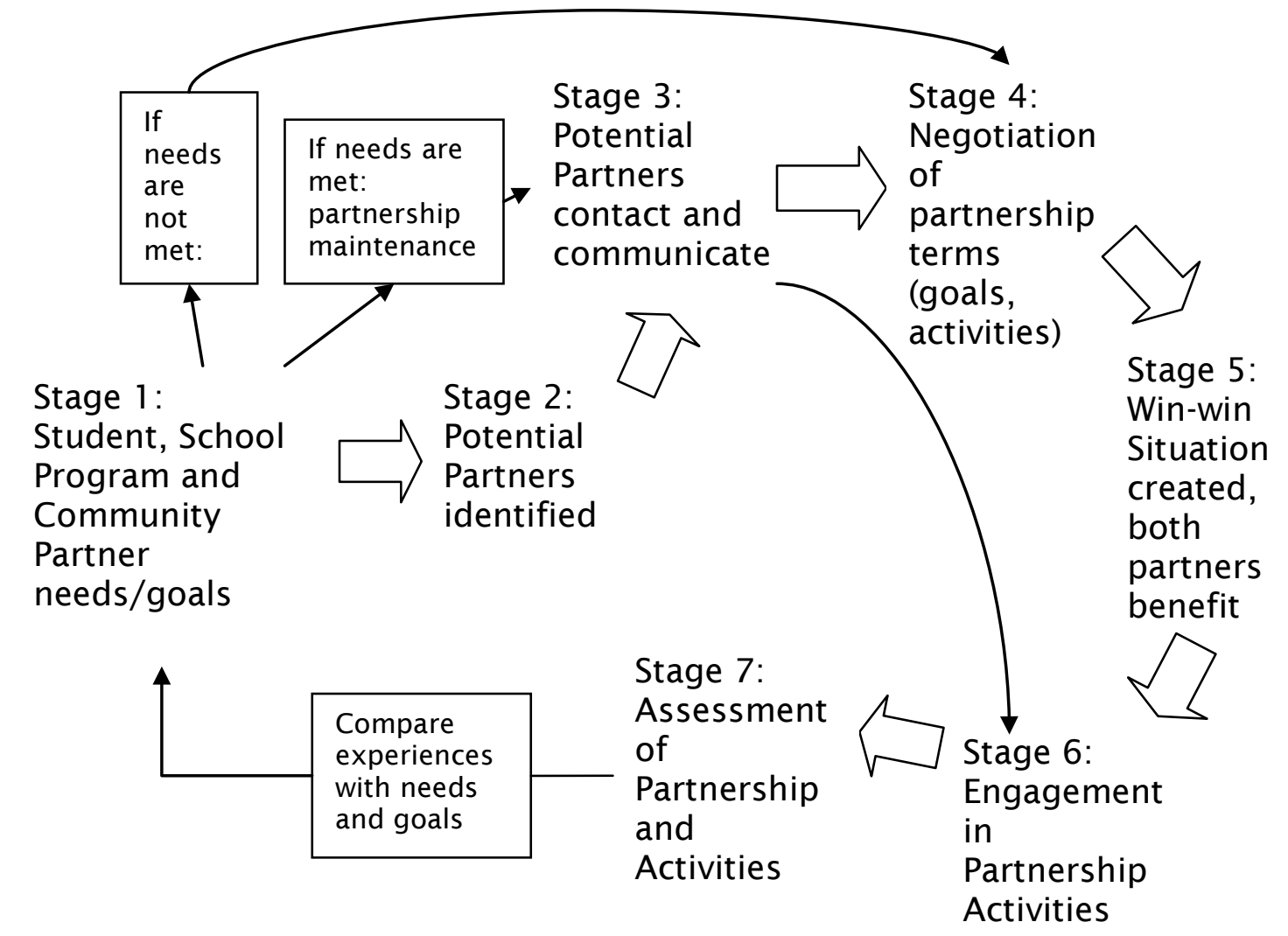

Figure 1': The Lifecycle of the Partnership Process.

Partnerships are based primarily on the students' needs, and potential partners at the school and in the community are sought and contacted based on the needs. During face-to-face meetings, school personnel and the community members discuss possibilities for partnering and establish partnership activities, in which both parties benefit. Feedback between the partners is provided when they assess the success of the activities in meeting their goals. Partners communicate their evaluations to one another in an ongoing manner, and if necessary, modify the partnership or the activities to suit their needs over time. 
In this article, I describe this process through a series of four key questions educators need to ask themselves, as they establish relationships with community members and organizations.

\section{What are our goals for school-community collaboration?}

Collaboration can supplement students’ learning experiences above and beyond those in school (Hands, 2005b). One department head advises, "You have to go with a strong sense of what it is you want to do. And how it's going to meet the needs of your kids” (Hands, 2005b). Educators are encouraged to reach out to parents and community members beyond the walls of the school, and initiate school-community collaborative activities (Hands, 2005b; Epstein, 1995, 2001; Sanders, 1999; Sheldon, 2005). In explaining why she and her colleagues involve the community, one educator had this to say:

It's driven on need, because that's the only reason—we've got enough on our plate, but you know, if another need pops up, well we're doing it. Yeah, I think it's run by need. The needs of our students, or what's needed in the community, whether it is in school or outside, because that's what drives your program. It's what drives mine. (Hands, 2005a, p. 85)

That said, collaborative activities are most effectively created when all parties are involved in the planning (Hands, 2005b). Action teams, or steering committees, can be instrumental in deciding on goals for collaborative activities (Epstein, 1995; Sanders, 1999). These action teams typically include teachers, members of the school administration, parents, community members, and students (Sanders, 1999). Together, the action team members identify the students' and their families' needs (Epstein, 1995), school needs, as well as community needs (Hands, 2005b, 2009a), and work together to develop collaborative activities that focus on student support, family support, school improvement, and community development (Sanders, 2001) (see Figure 1).

In places where it is not possible to create a separate action team for collaboration, some schools and boards in Ontario use their school councils for this purpose. A supervisory officer and/or school principal, train the school council members to evaluate the demographics in their school communities, and develop activities based on their students', families', and schools’ needs that are consistent with their schools’ goals for student achievement and wellbeing 
(Epstein, 1995, 2001; Hands, 2011). While there is very little, if any, research on schools that involve families and community members in the development of these broader goals, this does not mean that community members and families could not be involved. Community characteristics (e.g., types of natural resources, organizations and businesses available, the ethnic and religious makeup of the population, the size of the population, etc.) shape the needs of the students, as well as the needs of their families, and the schools located in the community (Hands, 2005b; Lin, 1999). As such, members of the community may be in a valuable position to identify needs, and to share knowledge with the educators who may or may not live in the community (Hands, 2005b). Furthermore, scholars such as Susan Auerbach (2010) and Novella Keith (1999), highlight the importance of developing authentic partnerships, in which educators, families, and community members share knowledge and power in decision-making regarding educational issues. It is likely that this level of communication and engagement leads to the development and promotion of respect and trust that Joyce Epstein (1995) notes is essential to collaboration.

\section{How do we connect with potential partners?}

Once members of the action team identify the goals for collaborative activities based on needs and the school's goals, it is time to decide who in the community would share an interest in specific goals (Hands, 2005b; Sanders, 2001). Potential community partners may come from the public, for-profit, and non-profit sectors (Wohlstetter, Malloy, Smith, \& Hentschke, 2003). Examples of organizations from these sectors include universities and other schools, faith-based organizations, cultural and recreational centres, and individuals with an interest in working with educators and their students. (A more complete list of organizations is included in Table 1.) The types of available community collaborators depend on the community’s characteristics (Hands, 2005b; Lin, 1999); urban areas likely have a variety of large and small businesses, hospitals, school boards and their schools, universities and colleges, as well as an assortment of cultural centres and faith-based organizations, while more rural areas may have recreational centres, public libraries, health care facilities, and fewer businesses, for example (Hands, 2005b). When thinking about who might make a good collaborator, it is helpful to first consider the citizens and types of community organizations nearby. Organizations that are located close by are often the most effective partners, since the opportunities needed to meet face-to-face to develop the 
relationship and engage in the activities are not always possible at a physical distance (Hands, 2005a).

Table 1

Community Partners for Collaboration

\begin{tabular}{|c|c|c|c|}
\hline $\begin{array}{l}\text { Public Sector } \\
\text { Organizations }\end{array}$ & $\begin{array}{c}\text { For-Profit Sector } \\
\text { Organizations }\end{array}$ & $\begin{array}{l}\text { Non-Profit Sector (social } \\
\text { service organizations) }\end{array}$ & $\begin{array}{c}\text { Community } \\
\text { Citizens }\end{array}$ \\
\hline 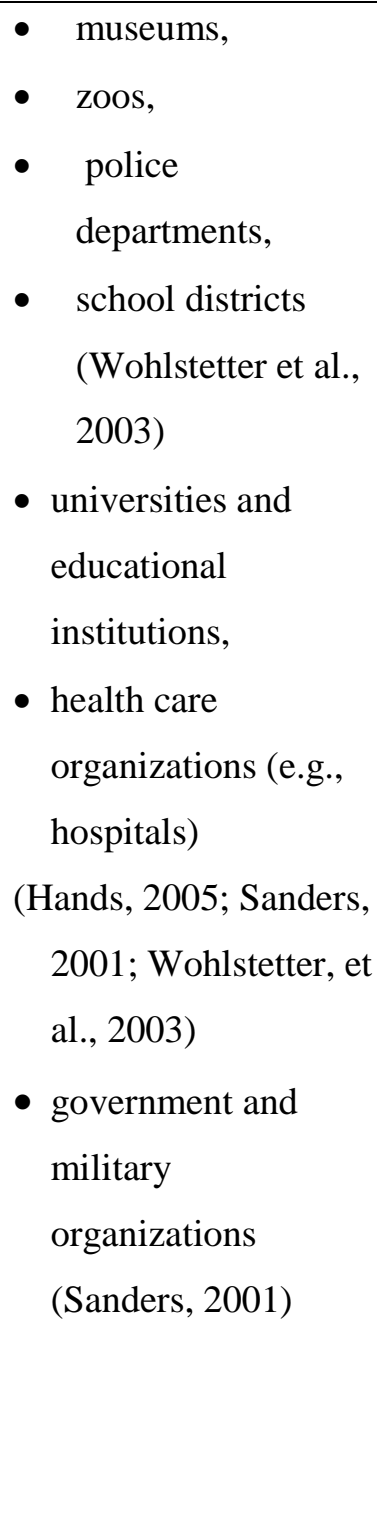 & $\begin{array}{l}\text { • Educational } \\
\text { Management } \\
\text { Organizations } \\
\text { (EMOs) (i.e., } \\
\text { organizations or } \\
\text { firms that } \\
\text { manage public } \\
\text { schools, } \\
\text { including } \\
\text { charter schools) } \\
\text { (Wohlstetter, et al., } \\
\text { 2003) } \\
\text { • businesses } \\
\text { (accounts for } \\
\text { most school- } \\
\text { community } \\
\text { collaboration) } \\
\text { (Hands, 2005; } \\
\text { Sanders, 2001; } \\
\text { Wohlstetter, et } \\
\text { al., 2003) }\end{array}$ & $\begin{array}{l}\text { - health clinics (e.g., mental } \\
\text { wellness centres, child and } \\
\text { youth counseling services), } \\
\text { - community development } \\
\text { organizations, } \\
\text { - } \text { shelters for abused children, } \\
\text { - cultural organizations, } \\
\text { - } \text { non-profit EMOs, } \\
\text { - community-based } \\
\text { organizations (e.g., Boys and } \\
\text { Girls Clubs, Girl Guides, the } \\
\text { YMCA) (Wohlstetter, et al., } \\
\text { 2003) } \\
\text { - senior citizens' } \\
\text { organizations, } \\
\text { - cultural and recreational } \\
\text { institutions, } \\
\text { - faith organizations, } \\
\text { (Hands, 2005; Sanders, 2001) } \\
\text { • national service and } \\
\text { volunteer organizations (e.g., } \\
\text { (Sions, Rotary), } \\
\text { (Sanders, 2001) }\end{array}$ & $\begin{array}{l}\text { - individual } \\
\text { community } \\
\text { members with } \\
\text { an interest in } \\
\text { education } \\
\text { (Sanders, } \\
\text { 2001) }\end{array}$ \\
\hline
\end{tabular}

When educators have identified their goals for collaboration and potential community partners, they contact them to discuss their ideas (Sanders, 2001). Typically, the initiator of the 
collaboration makes cold calls or contacts someone in his or her personal or professional network, or someone in a friend's or colleague’s network (Hands, 2005b). For school boards with community liaison officers, school personnel can contact these central office staff members to identify a potential partner and to make the initial contact. Of the two strategies, contacting a friend, acquaintance, or colleague (and their friends or acquaintances) is the most effective way to recruit partners; as an educator in one research study observed, "It really helps to have some kind of network, it really is more effective when you know that person. They find it hard to just say no, I think” (Hands, 2005b, p. 74). More than this, though, there is a level of trust that already exists, which makes it easier to create collaborative activities, because they are built on a relationship (Hands, 2009b).

Often, the first contact is a voice or e-mail message. It is important to be clear about the goals, as well as the potential benefits for not only the school, but for the potential partner in any messages (Hands, 2005b). Without brief but clear communication, it is not likely that community members will see the benefit of collaborating and pursue a relationship. One department head in a research study put it this way:

I think in the society we live in, people are very busy, and the first question is going to be, "Well, what's in it for me?” So, rather than waste people’s time, you have to present it like, "This is a situation which will benefit us both.” So, yeah, I think there has to be some reciprocation. And it has to be obvious. (Hands, 2005b, p. 71)

\section{How do we see community members, educators, students, and support staff working together?}

While collaborative activities can be developed via the internet (Hands, 2011), the most effective way is with a face-to-face meeting (Hands, 2005). With all potential partners present, opportunities to socialize before negotiating terms for collaboration seem to help pave the way for those discussions. "The meetings [at the school] and [at the college] were, you know, partly filled with faculty and people talking about their great experiences teaching kids, and I think that that was a commonality that started the conversation”, according to a high school's college partner in one research study (Hands, 2005a, p. 93). In these first discussions, there is two-way communication of possible goals for the collaborative activities, with the intent of identifying 
shared goals (Sanders \& Harvey, 2002). More than that, though, these goals need to be flexible. The school's college partner observed,

I think just by keeping it as an open document, and kind of, evolving it as we have to and discussing things, leaving some things vague and some things open, I think that's the best way to do it, as long as the people involved understand the rules of the game, if you will; that it is open, that we can make modifications if we have to. (Hands, 2005b, p. 73)

Once some shared goals are established, school-community collaboration is possible. Further communication among all of the constituents can then focus on creating a win-win situation. All parties need to benefit from the relationship, and this is the phase in which the activities take shape. At this time, the partners develop specific activities to meet their goals, and they establish the activities' length. Some may be of shorter duration than others; for example, workplace internships or service learning opportunities might span a semester, or three or four months, while relationships with a college may be long-term and involve ongoing recruitment and student placements in college courses on an annual basis (cf. Hands, 2005b; Sanders, 2003).

\section{How do we know we are reaching our goals?}

Collaborative activities can be ongoing or intermittent, and they can be formal or informal; regardless, there needs to be an agreed-upon check-in time to make sure the relationship is working, and the shared goals are being met. Once the collaborative activities are developed and under way, the participants monitor and assess them (Sanders, 2001, 2003). This kind of monitoring needs two-way communication throughout the process, during the activities, and after a set period (Sanders \& Harvey, 2002). The collaborators compare the activities' results with their agreed-upon goals. If the participants’ needs are not being met, if possible they renegotiate the terms of the collaboration (Hands, 2005a). This requires the type of relationship flexibility previously mentioned. One school's community partner stated she would approach her partners and say, "Look, this is what I had envisioned.... Look what's happening. You know, I don't think this is what we envisioned in our original plans. So let's see how we can get the focus off of what we don’t want” (Hands, 2005a, p. 106). 
If the circumstances change for the people involved, the goals and strategies for reaching them need to change for the relationship to evolve and grow (Hands, 2005a). Failing that, the participants may decide to end the collaboration (Hands, 2005a). On the other hand, if the activities are benefiting everyone involved and meeting their goals, the successes are celebrated (Sanders, 2001), and the collaboration continues if desired.

\section{Putting School-Community Collaboration into Practice}

With a process for creating school-community collaboration and some strategies for setting up liaisons outlined, it is helpful to look at the types of activities that some schools have developed (examples from Hands, 2005, 2011; see Table 2). That said, the information that follows provides some ideas, but the needs of the school personnel and their programs, the students, their families, and the community members, drive the types of activities that are developed (Epstein, 1995, 2001; Hands, 2005a). Collaborative activities - even the same ones - look different depending on the families, school, and community (Hands, 2005a).

Table 2

Schools' Community Partners and their Collaborative Activities

\begin{tabular}{|c|c|c|c|c|}
\hline $\begin{array}{l}\text { Activity Focus } \\
\text { Partner Type }\end{array}$ & Student Centred & Family Centred & School Centred & $\begin{array}{l}\text { Community } \\
\text { Centred }\end{array}$ \\
\hline $\begin{array}{l}\text { For-Profit Sector } \\
\text { Businesses/ } \\
\text { Corporations }\end{array}$ & $\begin{array}{l}\text { Martial arts } \\
\text { academy teaches } \\
\text { self-defence } \\
\text { component of high } \\
\text { school Physical } \\
\text { Education } \\
\text { curriculum } \\
\text { Work placements } \\
\text { in grocery store } \\
\text { franchise's various } \\
\text { departments; } \\
\text { students can } \\
\text { complete their } 40 \\
\text { hours of } \\
\text { community service } \\
\text { Student work } \\
\text { placements in } \\
\text { doctor's office; } \\
\text { students take case } \\
\text { histories, patient }\end{array}$ & $\begin{array}{l}\text { Local fitness centre } \\
\text { teaches school } \\
\text { Physical Education } \\
\text { classes (Zumba, } \\
\text { aerobics); } \\
\text { encourages physical } \\
\text { fitness, provides } \\
\text { extracurricular } \\
\text { classes at centre and } \\
\text { in school to students } \\
\text { and their families } \\
\text { School partners with } \\
\text { local food services } \\
\text { and suppliers to host } \\
\text { meals at the school } \\
\text { periodically } \\
\text { throughout the year } \\
\text { for families in need; } \\
\text { for example, turkey } \\
\text { dinners at } \\
\text { Thanksgiving and }\end{array}$ & $\begin{array}{l}\text { Media } \\
\text { corporation (e.g., } \\
\text { Corus) donates } \\
\text { money and music } \\
\text { cds to school's } \\
\text { communications } \\
\text { and broadcasting } \\
\text { program; } \\
\text { provides } \\
\text { information and } \\
\text { guidance to } \\
\text { students about } \\
\text { media piracy }\end{array}$ & $\begin{array}{l}\text { Students in } \\
\text { school's } \\
\text { hospitality } \\
\text { department cater } \\
\text { local businesses' } \\
\text { meetings, } \\
\text { corporate events } \\
\text { School's carpentry } \\
\text { and woodworking } \\
\text { department has a } \\
\text { retail contract; } \\
\text { students build } \\
\text { wooden Muskoka } \\
\text { chairs for sale }\end{array}$ \\
\hline
\end{tabular}




\begin{tabular}{|c|c|c|c|c|}
\hline & $\begin{array}{l}\text { measurements } \\
\text { (weight/height), } \\
\text { learn how to give } \\
\text { needles, draw blood }\end{array}$ & $\begin{array}{l}\text { during religious } \\
\text { holidays }\end{array}$ & & \\
\hline $\begin{array}{l}\quad \text { Public Sector } \\
\text { University and } \\
\text { Educational } \\
\text { Institutions }\end{array}$ & $\begin{array}{l}\text { Activities between } \\
\text { elementary and } \\
\text { high schools; e.g., } \\
\text { reading buddies } \\
\text { and tutoring, } \\
\text { musical and } \\
\text { theatrical } \\
\text { performances }\end{array}$ & $\begin{array}{l}\text { Schools open their } \\
\text { facilities up to the } \\
\text { families in the } \\
\text { community after } \\
\text { hours: for example, } \\
\text { evening sports } \\
\text { activities in the } \\
\text { gymnasium, and } \\
\text { library hours for } \\
\text { families after school }\end{array}$ & $\begin{array}{l}\text { College } \\
\text { communications } \\
\text { program } \\
\text { guarantees a spot } \\
\text { in the program } \\
\text { for an incoming } \\
\text { high school } \\
\text { student; college } \\
\text { students have } \\
\text { access to school's } \\
\text { FM radio station }\end{array}$ & $\begin{array}{l}\text { Schools host } \\
\text { community } \\
\text { interest courses } \\
\text { offered through } \\
\text { the board at their } \\
\text { site; teachers or } \\
\text { administrators run } \\
\text { technology classes } \\
\text { for community } \\
\text { citizens (e.g., how } \\
\text { to use word } \\
\text { processing, } \\
\text { spreadsheets, iPad } \\
\text { apps, etc.) }\end{array}$ \\
\hline $\begin{array}{l}\text { Government \& } \\
\text { Military }\end{array}$ & $\begin{array}{l}\text { Public Health runs } \\
\text { programs for } \\
\text { students designed } \\
\text { to get their peers } \\
\text { interested in } \\
\text { wellness issues } \\
\text { Provincial } \\
\text { ministries (e.g., } \\
\text { Natural Resources) } \\
\text { has volunteers to } \\
\text { help staff run } \\
\text { programs on } \\
\text { limited budgets; } \\
\text { students develop } \\
\text { skills for beginning } \\
\text { working career }\end{array}$ & $\begin{array}{l}\text { Public Health } \\
\text { provides physical } \\
\text { and mental health } \\
\text { resources for } \\
\text { students and their } \\
\text { families through } \\
\text { school }\end{array}$ & $\begin{array}{l}\text { Public Health } \\
\text { provides } \\
\text { information to } \\
\text { supplement } \\
\text { curriculum on } \\
\text { health and } \\
\text { wellness }\end{array}$ & $\begin{array}{l}\text { Municipal offices } \\
\text { (e.g., leisure } \\
\text { services) involve } \\
\text { students in making } \\
\text { sails for street } \\
\text { lamp posts, } \\
\text { building benches } \\
\text { and planters for } \\
\text { parks }\end{array}$ \\
\hline $\begin{array}{l}\text { Public/Non-Profit } \\
\text { Sector } \\
\text { Health Care } \\
\text { Organizations }\end{array}$ & $\begin{array}{l}\text { Youth mental } \\
\text { health organization } \\
\text { has counselors in } \\
\text { school to provide } \\
\text { students with } \\
\text { mental health } \\
\text { support }\end{array}$ & $\begin{array}{l}\text { Child and youth } \\
\text { social services offer } \\
\text { programs for } \\
\text { children and their } \\
\text { families (i.e., } \\
\text { guidance } \\
\text { department or } \\
\text { administration can } \\
\text { be a liaison between } \\
\text { families and the } \\
\text { services) } \\
\text { Preventative health } \\
\text { care clinic set up at } \\
\text { the school for } \\
\text { students and their }\end{array}$ & $\begin{array}{l}\text { Personnel from } \\
\text { local hospitals, } \\
\text { dental and } \\
\text { medical clinics, } \\
\text { etc. conduct } \\
\text { workshops or } \\
\text { information } \\
\text { sessions for the } \\
\text { school } \\
\text { community (e.g., } \\
\text { dental hygiene, } \\
\text { adolescent health } \\
\text { issues such as } \\
\text { alcohol or drug } \\
\text { use, available } \\
\text { medical services) }\end{array}$ & $\begin{array}{l}\text { Service learning } \\
\text { placements are } \\
\text { created for } \\
\text { students in } \\
\text { hospitals, clinics, } \\
\text { etc. } \\
\text { Community health } \\
\text { fair hosted on } \\
\text { school grounds }\end{array}$ \\
\hline
\end{tabular}




\begin{tabular}{|c|c|c|c|c|}
\hline & & families & & \\
\hline $\begin{array}{l}\text { Non-Profit Sector } \\
\text { Senior Citizen’s } \\
\text { Organizations }\end{array}$ & $\begin{array}{l}\text { Students are paired } \\
\text { with } \\
\text { residents/members } \\
\text { at a seniors' facility } \\
\text { to do activities } \\
\text { together (e.g., play } \\
\text { games, learn to knit } \\
\text { or crochet, read) }\end{array}$ & $\begin{array}{l}\text { Seniors' volunteer } \\
\text { and service } \\
\text { organizations host } \\
\text { adult education } \\
\text { classes (e.g., } \\
\text { computer and IT), } \\
\text { provide speakers on } \\
\text { topics of interest }\end{array}$ & $\begin{array}{l}\text { School } \\
\text { hospitality, } \\
\text { hairstyling and } \\
\text { aesthetics } \\
\text { programs have } \\
\text { customers from } \\
\text { local seniors' } \\
\text { clubs; purpose of } \\
\text { programs is met } \\
\text { and students } \\
\text { practice skills }\end{array}$ & $\begin{array}{l}\text { Students perform } \\
\text { musical concerts } \\
\text { and theatrical } \\
\text { productions at } \\
\text { seniors' residences } \\
\text { and nursing homes }\end{array}$ \\
\hline $\begin{array}{l}\text { Faith-based, Cultural } \\
\text { \& Recreational } \\
\text { Organizations }\end{array}$ & $\begin{array}{l}\text { Internships or } \\
\text { community-based } \\
\text { education } \\
\text { placements at local } \\
\text { amateur and } \\
\text { professional } \\
\text { theatres; students } \\
\text { learn skills in } \\
\text { costume and prop } \\
\text { design, stage } \\
\text { management } \\
\text { Students work in } \\
\text { placements at } \\
\text { church conference } \\
\text { centre, setting up } \\
\text { for events, helping } \\
\text { with coordination }\end{array}$ & $\begin{array}{l}\text { Students develop } \\
\text { beginners' skating } \\
\text { classes for parents } \\
\text { and young children } \\
\text { at the sports arena } \\
\text { while older siblings } \\
\text { play hockey } \\
\text { Schools in newly } \\
\text { developed } \\
\text { neighbourhoods } \\
\text { without cultural or } \\
\text { recreational } \\
\text { facilities host family } \\
\text { social nights (e.g., } \\
\text { movie nights, games } \\
\text { nights, weekend } \\
\text { barbeques, etc.) }\end{array}$ & $\begin{array}{l}\text { Local First } \\
\text { Nations } \\
\text { community } \\
\text { members provide } \\
\text { aboriginal } \\
\text { language } \\
\text { instruction; } \\
\text { aboriginal } \\
\text { counselor at } \\
\text { school to assist } \\
\text { with student } \\
\text { issues } \\
\text { Leaders of } \\
\text { cultural groups } \\
\text { share traditions, } \\
\text { languages, } \\
\text { customs with } \\
\text { students and } \\
\text { educators }\end{array}$ & $\begin{array}{l}\text { Teacher of First } \\
\text { Nations heritage, } \\
\text { and First Nations } \\
\text { community } \\
\text { organize a pow } \\
\text { wow for the } \\
\text { broader } \\
\text { community } \\
\text { Community art } \\
\text { and crafts fair held } \\
\text { on school grounds }\end{array}$ \\
\hline $\begin{array}{l}\text { Other Community- } \\
\text { based Organizations } \\
\text { and Individuals }\end{array}$ & $\begin{array}{l}\text { Abuse prevention } \\
\text { organization } \\
\text { involves students in } \\
\text { performances at } \\
\text { schools to educate } \\
\text { other students } \\
\text { about abuse issues } \\
\text { Social } \\
\text { organizations (e.g., } \\
\text { Rotary Club) run } \\
\text { leadership training } \\
\text { workshops for } \\
\text { youth }\end{array}$ & $\begin{array}{l}\text { Child care centre in } \\
\text { school; students get } \\
\text { experience working } \\
\text { in ECE setting, } \\
\text { children and } \\
\text { families have access } \\
\text { to school's } \\
\text { resources }\end{array}$ & $\begin{array}{l}\text { Citizens involved } \\
\text { in school council; } \\
\text { share their } \\
\text { knowledge of the } \\
\text { community and } \\
\text { its resources to } \\
\text { build } \\
\text { programming } \\
\text { Dairy Farmers of } \\
\text { Ontario provide } \\
\text { curriculum } \\
\text { resources (e.g., } \\
\text { nutrition } \\
\text { information and } \\
\text { materials) }\end{array}$ & $\begin{array}{l}\text { Education-focused } \\
\text { organization } \\
\text { provides materials } \\
\text { to students, } \\
\text { teacher training } \\
\text { workshops to } \\
\text { deliver program } \\
\text { (e.g., Investigate, } \\
\text { Invent, and } \\
\text { Innovate!), } \\
\text { students solve } \\
\text { problems } \\
\text { identified in their } \\
\text { community }\end{array}$ \\
\hline
\end{tabular}


Creating school-community collaboration across all sectors and involving all types of organizations is a daunting task if done all at once. It may be that not all types of organizations are available or meet the needs of the students, their families, and the school. That said, it is important to seek out those organizations that are, and do. Some schools have upwards of 75 or 80 partnerships at any given time (Hands, 2005b), but it is important to note that these relationships were developed over time. It is helpful to prioritize any needs, before seeking out community members for a potential partnership. As well as networking, some ideas for activities come from professional learning. Attending workshops and conferences, having opportunities for interacting with community members at regional educators meetings, and hearing from other educators about their community engagement, are all good ways of making new associations and learning about collaborative activities (Hands, 2005a).

\section{Going Forward: Expected Results}

The collaborative work among educators, policy-makers, families, community citizens, and researchers has contributed to our understanding of school-community relations. Moving forward, it is likely that these relationships will retain an important role in education. As such, the main purpose of this article is to provide educators who are interested in developing schoolcommunity relationships with an overview of school-community interaction, and some strategies for creating collaborative activities, as well as some sample activities. While they establish the relationships, educators may find it useful to consider:

- their goals for school-community collaboration,

- how they will connect with potential partners,

- how they envision community members, educators, students, and support staff working together, and

- $\quad$ how they will know they are reaching their goals.

Interested educators can use the tools offered in this article to organize their work in this area. To assist in the process, it is sometimes helpful to have a "critical friend"; someone who understands the complexities of the school's context, who can ask insightful questions and provide data and its interpretation through a different perspective, and who can provide critique about what is going on at the school (Costa \& Kallick, 1993). For example, I have in the past worked, and 
continue to work closely with schools and their action teams, to provide clear strategies for this work and to help school communities tailor collaboration plans to their needs.

We have found that the work involved in developing school-community liaisons pays off. The process of developing these interactions can do much to promote authentic partnerships: "respectful alliances among educators, families, and community groups that value relationship building, dialogue, and power sharing as a part of socially just, democratic schools” (Auerbach, 2010, p. 729). This helps to build mutual respect with a focus on student achievement and wellbeing (Pushor, 2007). Through these relationships, students have opportunities to build skills they might not otherwise have the opportunity to develop, as well as to build their resources and their access to resources through their expanding community networks (Hands, 2005; Mawhinney, 2002). In the process, the students are able to put into practice what they learn at school, which enhances educational relevance. More broadly, school-community collaboration provides the human, material, and financial resources to enrich the programming offered at the schools (Epstein, 1995; Hands, 2005b; Sanders, 2003; Sanders \& Harvey, 2002). Lastly, and perhaps most importantly, school-community connections have the potential to promote civicminded individuals who contribute positively to their communities (Hands, 2005b; Westheimer \& Kahne, 2004). Community involvement in education is not a substitute for "sound educational policies, adequate funding or excellent teaching. It can, however, ... be the little extra that makes the big difference” (Sanders, 2003, p. 176).

\section{Notes}

1. The lifecycle of partnerships and its description in Figure 1 first appears in Hands, C. (2005b). It's who you know and what you know: The process of creating partnerships between schools and communities. The School Community Journal, 15(2), 63-84.

Catherine Hands is currently appointed as an Associate Professor at Brock University, where she teaches in the Administration and Leadership in Education program in the Faculty of Education. As a researcher, teacher and consultant, Catherine has worked with Ontario school boards, the Elementary Teachers' Federation of Ontario, and the Ontario Ministry of Education's Parent Engagement Office. Catherine's research interests stem from her experiences in the classroom, as well as her work with school leaders and teachers, and include school-community relations, family involvement in schooling, schools as communities, educational leadership, values and ethics in education, social justice, professional learning communities, and educational reform. She maintains an active research agenda in these areas, and has presented and published her work regionally, nationally and internationally. 


\section{References}

Auerbach, S. (2010). Beyond coffee with the principal: Toward leadership for authentic school-family partnerships. Journal of School Leadership, 20, 728-757.

Coleman, J. S. (1988). Social capital in the creation of human capital. American Journal of Sociology, 94, Supplement, S95-S120.

Costa, A., \& Kallick, B. (1993). Through the lens of a critical friend. Educational Leadership, 51(2), 49-51.

Crowson, R. L., \& Boyd, W. L. (2001). The new role of community development in educational reform. Peabody Journal of Education, 76(2), 9-29.

Epstein, J. L. (1995). School/family/community partnerships: Caring for the children we share. Phi Delta Kappan, 76(9), 701-712.

Epstein, J. L. (2001). School, family, and community partnerships: Preparing educators and improving schools. Boulder, CO: Westview Press.

Epstein, J. L., \& Sanders, M. G. (1998). What we learn from international studies of schoolfamily-community partnerships. Childhood Education, 74(6), 392-394.

Gregoric, C. (2013). School-community involvement. Mitcham, Australia: UNESCOAPNEIVE Australia.

Hands, C. (2005a). Patterns of interdependency: The development of partnerships between schools and communities. Unpublished doctoral dissertation. Toronto, Ontario, Canada: Ontario Institute for Studies in Education, University of Toronto.

Hands, C. (2005b). It's who you know and what you know: The process of creating partnerships between schools and communities. The School Community Journal, 15(2), 63-84.

Hands, C. (2009a, April). Efforts to enhance parent engagement: What can we learn from an assemblage of district-wide initiatives? Paper presented at the annual meeting of the American Educational Research Association, San Diego, CA, 43 pp.

Hands, C. M. (2009b). The evolution of trust relationships in school-community partnership development: From calculated risk-taking to unconditional faith. In L. Shumow (Ed.), Promising practices for family and community involvement during high school (pp. 5369). Greenwich, CT: Information Age Publishing.

Hands, C. M. (2011, April). “It’s part of contributing to global citizenship”: Students’ and teacher leaders’ perspectives on school-community partnerships. Paper presented at the annual meeting of the American Educational Research Association, New Orleans, LA, 23 pp.

Hands, C. M. (2013). Including all families in education: School district-level efforts to promote parent engagement in Ontario, Canada. Teaching Education, 24(2), 134-149.

Hands, C. M. (2014). Youth perspectives on community collaboration: Are students innovative developers, active participants, or passive observers of collaborative activities? The School Community Journal, 24(1), 69-97.

Henderson, A. T., \& Mapp, K. L. (2002). A new wave of evidence: The impact of school, family, and community connections on student achievement. Austin, TX: Southwest Educational Development Laboratory.

Henderson, A. T., Mapp, K. L., Johnson, V. R., \& Davies, D. (2007). Beyond the bake sale: The essential guide to family-school partnerships. New York, NY: The New Press.

Keith, N. Z. (1999). Whose community schools? New discourses, old patterns. Theory Into 
Practice, 38(4), 225-234.

Lin, N. (1999). Building a network theory of social capital. Connections, 22(1), 28-51.

Mawhinney, H. B. (2002). The microecology of social capital formation: Developing community beyond the schoolhouse door. In G. Furman (Ed.), School as community: From promise to practice (pp. 235-255). Albany, NY: State University of New York Press.

Merz, C., \& Furman, G. (1997). Community and schools: Promise and paradox. New York, NY: Teachers College Press.

Ontario Ministry of Education. (2005, December). Developing partners in education. Retrieved from http://www.edu.gov.on.ca/eng/document/nr/05.12/developing.pdf

Pushor, D. (2007, January). Parent engagement: Creating a shared world. Paper presented at the Ontario Education Research Symposium, Toronto, Ontario, Canada.

Sanders, M. G. (1999). Schools’ program and progress in the National Network of Partnership Schools. The Journal of Educational Research, 92(4), 220-232.

Sanders, M. G. (2001). The role of “community” in comprehensive school, family, and community programs. The Elementary School Journal, 102(1), 19-34.

Sanders, M. G. (2003). Community involvement in schools: From concept to practice. Education and Urban Society, 35(2), 161-180.

Sanders, M. G., \& Harvey, A. (2002). Beyond the school walls: A case study of principal leadership for school-community collaboration. Teachers College Record, 104(7), 13451368.

Schutz, A. (2006). Home is a prison in the global city: The tragic failure of school-based community engagement strategies. Review of Educational Research, 76(4), 691-743.

Shapiro, J. P., Ginsberg, A. E., \& Brown, S. P. (2002, October). Family and community participation in urban schools: The ethic of care. Paper presented at the $7^{\text {th }}$ annual Values and Leadership in Education conference, Toronto, Ontario, Canada.

Sheldon, S. B. (2005). Testing a structural equation model of partnership program implementation and parent involvement. The Elementary School Journal, 106(2), 171187. [Electronic version.]

Westheimer, J., \& Kahne, J. (2004). Educating the "good” citizen: Political choices and pedagogical goals. Political Science \& Politics, 38(2), 1-7.

Wohlstetter, P., Malloy, C. L., Smith, J., \& Hentschke, G. (2003). Cross-sectorial alliances in education: A new approach to enhancing school capacity. (Working paper). Los Angeles: University of Southern California, Rossier School of Education, Center on Educational Governance. 